\title{
Soil-Test-Based Phosphorus Recommendations for Commercial Agricultural Production in Florida ${ }^{1}$
}

\author{
Rao Mylavarapu, Yuncong Li, Maria Silveira, Cheryl Mackowiak, and Mabry McCray ${ }^{2}$
}

\section{Scope}

This document is intended to address agronomic and environmental issues related to phosphorus $(\mathrm{P})$ dynamics in Florida agricultural soils and soil test $\mathrm{P}$ interpretation and management for agricultural crops. This document aims to provide science-based information to agricultural clientele, including commercial producers, small farmers, Extension agents, crop consultants, landscape professionals, representatives of the fertilizer industry, state and local agencies, students and instructors of high schools and colleges, researchers, and interested Florida citizens.

\section{Background}

Phosphorus is an essential element for plant growth and agricultural productivity. Soil $\mathrm{P}$ exists in both organic and inorganic forms. Organic $P$ forms account for approximately $65 \%$ or less of total soil $\mathrm{P}$ and are mainly derived from humus, phospholipids, and nucleic acids. The organic matter content in coastal plain sands of the Southeast and South (the predominant soil type in Florida) tends to be lower compared to northern regions of the United States (Mylavarapu et al. 2014). Soil inorganic P includes calcium (Ca), iron ( $\mathrm{Fe})$, and aluminum ( $\mathrm{Al})$ phosphates, compounds with varying solubilities, along with orthophosphates. Although inorganic P generally accounts for $35 \%$ or more of total soil P, dissolved $\mathrm{P}$ in soil solution is typically less than 5 ppm. Crop P requirements must be assessed and managed more carefully than some other nutrients in order to provide for adequate plant uptake, while minimizing $\mathrm{P}$ losses from agricultural fields. When soil $\mathrm{P}$ deficiencies are identified through soil and tissue testing, $\mathrm{P}$ recommendations are based on the amount of $P$ required to meet the crop nutrient requirements during the current growing season. High-value crops in some circumstances may demand greater fertilizer inputs to obtain economical crop yields. Over-application of $\mathrm{P}$ at levels that exceed crop requirements and/or exceed the P-holding capacity of the soil can result in negative economic and environmental consequences, such as soil $\mathrm{P}$ accumulation and subsequent off-site transport (i.e., leaching and runoff). In the predominantly sandy-textured soils of peninsular Florida, $\mathrm{P}$ can also leach vertically down the soil profile.

\section{P Dynamics in Florida Soils}

A number of soil properties, along with site-specific characteristics, affect $\mathrm{P}$ management in agricultural production systems.

\section{Plant-Available Forms}

Plants predominantly take up inorganic forms of nutrients, and the two inorganic forms of $\mathrm{P}$ are primary orthophosphate forms $-\mathrm{H}_{2} \mathrm{PO}_{4}^{-}$(the predominant form in acid soils) and $\mathrm{HPO}_{4}^{2-}$ (the predominant form in calcareous soils).

1. This document is SL486, one of a series of the Department of Soil and Water Sciences, UF/IFAS Extension. Original publication date February 2021. Visit the EDIS website at https://edis.ifas.ufl.edu for the currently supported version of this publication.

2. Rao Mylavarapu, professor, Department of Soil and Water Sciences, and director, UF/IFAS ANSERV Laboratories; Yuncong Li, professor, Department of Soil and Water Sciences, UF/IFAS Tropical Research and Education Center; Maria Silveira, professor, Department of Soil and Water Sciences, UF/ IFAS Range Cattle REC; Cheryl Mackowiak, associate professor, Department of Soil and Water Sciences, UF/IFAS North Florida REC; and Mabry McCray, agronomist, UF/IFAS Everglades REC; UF/IFAS Extension, Gainesville, FL 32611.

The Institute of Food and Agricultural Sciences (IFAS) is an Equal Opportunity Institution authorized to provide research, educational information and other services

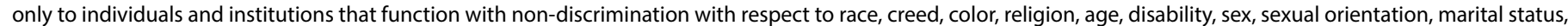

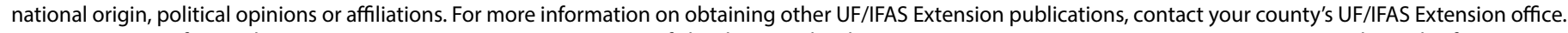
U.S. Department of Agriculture, UF/IFAS Extension Service, University of Florida, IFAS, Florida A \& M University Cooperative Extension Program, and Boards of County Commissioners Cooperating. Nick T. Place, dean for UF/IFAS Extension. 


\section{Mobility in Soils and in Plants}

Inorganic $\mathrm{P}$ is typically immobile in soils because it is subject to fixation with $\mathrm{Al}$ and Fe compounds in acid soils and $\mathrm{Ca}$ in alkaline soils, rendering the $\mathrm{P}$ into insoluble forms. Therefore, soluble $\mathrm{P}$ can be sorbed in soils and become unavailable quickly after application for both high- and low-pH soils, and in the presence of $\mathrm{Ca}$ or $\mathrm{Al}$ and Fe, respectively.

However, once inorganic $\mathrm{P}$ is absorbed through roots, $\mathrm{P}$ becomes mobile within the plants. Therefore, P-deficiency symptoms can first be noticed in the older developed leaves, because they are sacrificed to support $\mathrm{P}$ nutrition for younger, expanding leaves.

\section{Soil Variability}

In addition to topography, soil physical and chemical properties vary widely in Florida. For instance, soil thickness, water table depth, seasonal water table fluctuation, soil texture, soil reaction $(\mathrm{pH})$, organic matter content, relative P sorption capacity, etc. vary widely across soil types. Despite the wide range of soil types, the predominantly sandy soils in Florida have minimal P-retention capacity, and therefore $\mathrm{P}$ can be subject to leaching.

Additionally, the surface horizon of certain soils, such as Spodosols, contains limited amounts of $\mathrm{Fe}$ and $\mathrm{Al}$ compounds, which consequently diminished the capacity to retain added P. Conversely, the subsurface spodic horizon of Spodosols often retains significant amounts of $\mathrm{P}$ in forms that can be utilized by plants, but the roots cannot reach or penetrate the hardened spodic horizon. Additional details on Florida soils and soil fertility can be obtained from EDIS publication SL 441, Agricultural Soils of Florida (Mylavarapu, Harris, and Hochmuth 2019).

\section{P Solubility}

Just like for most other nutrients, $\mathrm{P}$ solubility in soils is mostly governed by soil $\mathrm{pH}$. Research studies have long established the solubility $\mathrm{pH}$ range in soils to be between 6.0 and 6.5 for P. Unless soil $\mathrm{pH}$ is managed between 6.0 and 6.5, it is likely that $P$ is soluble and less plant-available. Both Fe and $\mathrm{Al}$ compounds dominate the soil environment below $6.0 \mathrm{pH}$ in acid soils, and Ca compounds overwhelm soils with $\mathrm{pH}$ above 7.4.

Phosphorus solubility is also driven by diffusion to maintain equilibrium with the surrounding soil solution, which is typically $<5 \mathrm{ppm}$.

\section{Soil Testing for $\mathbf{P}$}

Routine soil fertility tests usually refer to a relatively rapid nutrient extraction resulting in an available soil nutrient value that is correlated with crop response to fertilization. Examples of commonly used soil nutrient extractants are Mehlich-1 (M1) and Mehlich-3 (M3) (Zhang et al. 2014), which are mostly used for fertilizer $\mathrm{P}$ and $\mathrm{K}$ rate recommendations. Although most modern soil test laboratories use similar soil extraction and quality control procedures along with comparable instrumentation, fertilizer rate recommendations from each laboratory may differ somewhat, even when numerical soil test results are identical (Liuzza et al. 2020; Sharpley et al. 2017). The reason is that numerical soil test values are interpreted according to the field research results observed locally in individual states. Therefore, soil P index categories of very low, low, moderate, high, and very high are established for each commodity in each state based on ranges of extractable P. The soil fertility laboratories and professionals that also interpret soil test results may have different fertilization philosophies. Although multistate collaborations have addressed nutrient management concerns across states (Brown 2012; Heckman et al. 2006; Miller, Gavlak, and Horneck 2013; Kitchen et al. 2017), the primary objectives of public soil testing programs remain to develop sound nutrient recommendations based on science and to standardize soil test procedures and soil test interpretations that produce accurate recommendations for similar crops and soils (Chuan et al. 2013; Mylavarapu et al. 2002).

The M1 extractant is especially suited to acidic and loworganic-matter mineral soils of the southeastern United States (Mylavarapu et al. 2002), but it is less reliable when used in near-neutral $(\mathrm{pH}>6.0)$ or calcareous soils having high cation exchange capacity (CEC) and high base saturation (Holford 1980; Peaslee 1978). In recent years, a number of laboratories in the southeastern United States have adopted M3 as the official method of extraction, replacing M1 and other methods, because M3 is suitable for a wider soil $\mathrm{pH}$ range when compared to $\mathrm{M} 1$, and it can be used to simultaneously extract multiple nutrients (Zhang et al. 2021, in revision). Therefore, the M3 procedure is the best-suited extraction procedure for soil testing across the wide range of soils and ecosystems in Florida.

Crucial to the success of soil testing is developing standardized procedures (extractant and analytical methods), test interpretation, and nutrient recommendations, all based on field calibration and validation. Detailed information on soil testing, soil test extractants, and the correlation and 
calibration processes, along with fertilizer recommendation policies, can be found in the following EDIS documents:

\section{Soil Testing for Plant-Available Nutrients-What Is It and} Why Do We Use It? (SL 408)

\section{Developing a Soil Test Extractant: The Correlation and Calibration Processes (SL 409)}

\section{Fertilizer Recommendation Philosophies (SL410)}

\section{Extraction of Soil Nutrients Using Mehlich-3 Reagent for Acid-Mineral Soils of Florida (SL 407)}

Traditional soil testing and field calibration and validation have gradually lost grant funding as priorities have shifted to water quality since the 1990s. In Florida, current recommendations have been calibrated and validated to a limited extent as a part of other water quality studies. Validation of Mehlich-3 based interpretation and recommendation was done at different locations and on different crops as a result of funding from FDACS and FDEP for 2 years. No response to $\mathrm{P}$ applications above UF/IFAS-recommended rates was recorded in these studies, except that in one case the soils tested low $(<25 \mathrm{ppm})$ in P. Studies were conducted across two seasons on tomatoes in south Florida and southwest Florida, lettuce in the Everglades Agricultural Area (EAA), and peanuts in north central Florida. All other crops were studied for only one season (Mylavarapu, Hochmuth, et al. 2018; Mylavarapu, Morgan, et al. 2018).

\section{Soil pH and Gypsum}

Soil $\mathrm{pH}$ management is the most important step for successful agricultural production. However, soil $\mathrm{pH}$ levels in Florida mineral soils have been shifting higher in several locations, along with organic soils in the EAA. Reasons for increasing soil $\mathrm{pH}$ levels in Florida soils and possible solutions can be found in SL 437 (Mylavarapu et al. 2019). Nutrients, particularly P, will be much less soluble and therefore plant-available at soil $\mathrm{pH}$ above 7.0. Due to several reasons related to management, at times the soil $\mathrm{pH}$ in naturally acidic regions can result in elevated $\mathrm{pH}$ levels (into the alkaline range with soil $\mathrm{pH}>7.0$ ). In such cases, lowering soil $\mathrm{pH}$ to 6.0-6.5 range can help increase availability of several plant essential nutrients along with $P$. However, lowering $\mathrm{pH}$ in naturally calcareous soils, such as those in Miami-Dade County, which have high calcium carbonate content, should not be attempted.

Florida vegetable growers are typically known for applying a significant amount of gypsum $\left(\mathrm{CaSO}_{4}\right)$ to their fields at planting, particularly for crops such as tomato, potato, pepper, melons, etc. Addition of high amounts of calciumrich soil amendments, such as gypsum $\left(\mathrm{CaSO}_{4}\right)$, is a regular part of the nutrient programs in vegetable production systems across the state. Limited information in published research is available on the benefits of high gypsum application to Florida vegetable crops. Calcium in the rootzone will alter the $\mathrm{P}$ sorption chemistry, and almost all of the applied $\mathrm{P}$ may be immediately rendered unavailable at soil $\mathrm{pH}>7.0$.

\section{Site-Specific Soil Test Interpretations}

To address the variability in soil properties within a production system, as well as variations across the state, standardization of soil test procedures and interpretations to soil tests should be developed based on site-specific conditions and local management styles. For the purposes of soil testing, Florida soils have been separated into three categories: acid-mineral, muck, and calcareous soils.

\section{Acid-Mineral Soils}

For the predominant acid-mineral soils of Florida, where Mehlich-3 extractant is used, the interpretation of soil tests is as shown below.

Table 1. Soil test interpretation for Mehlich-3 extraction method for agronomic and horticultural crops and landscapes $\left(\mathrm{mg} \mathrm{kg}^{-1}\right)$

\begin{tabular}{|c|c|c|c|}
\hline Nutrient & \multicolumn{3}{|c|}{ Interpretation (mg kg-1) } \\
\hline & Low & Medium & High \\
\hline $\mathrm{P}$ & $\leq 25$ & $26-45$ & $>45$ \\
\hline $\mathrm{K}$ & $\leq 35$ & $36-60$ & $>60$ \\
\hline $\mathrm{Mg}$ & $\leq 20$ & $21-40$ & $>40$ \\
\hline
\end{tabular}

\section{Organic (Muck) Soils}

Similarly, for organic (muck) soils in the EAA, the Mehlich-3 method is used for $\mathrm{P}$ estimation, and it includes a unique interpretation for sugarcane producers of the region (Table 2 ). For vegetables and field corn, a water extraction method is used (see Table 3 ).

Banding P fertilizer is a BMP for sugarcane in the EAA, with the objectives of increasing crop availability of $\mathrm{P}$ and reducing $\mathrm{P}$ rates. Because sugarcane is a perennial multiyear crop, it is difficult to obtain representative soil samples on which to base fertilizer for ratoon crops after banding the fertilizer in previous years. Therefore, the recommendations for each crop in Table 2 are based on preplant soil samples. Research results of decline in soil test values over time were 
used to develop the ratoon $\mathrm{P}$ recommendations based on expected soil test values and crop $\mathrm{P}$ requirements.

Table 2. Recommended phosphorus fertilizer for each sugarcane crop based on preplant Mehlich-3 extractable phosphorus (Pm) for sugarcane grown on organic soils in the Everglades Agricultural Area.

\begin{tabular}{|c|c|c|c|c|}
\hline Pm Index & Plant & Ratoon 1 & Ratoon 2 & Ratoon 3+ \\
\hline $\mathbf{g} / \mathbf{m}^{3}$ & \multicolumn{4}{|c|}{ lb $\mathbf{P}_{2} \mathbf{O}_{5} /$ acre } \\
\hline$\leq 8$ & 75 & 75 & 60 & 50 \\
\hline $9-15$ & 60 & 60 & 50 & 50 \\
\hline $16-20$ & 50 & 50 & 40 & 40 \\
\hline $21-25$ & 40 & 40 & 40 & 40 \\
\hline $26-30$ & 0 & 30 & 30 & 40 \\
\hline $31-35$ & 0 & 0 & 20 & 30 \\
\hline $36-40$ & 0 & 0 & 0 & 20 \\
\hline$>40$ & 0 & 0 & 0 & 0 \\
\hline
\end{tabular}

\section{Calcareous Soils}

For calcareous soils of Miami-Dade County, the mostly ineffective AB-DTPA soil extractant procedure has been replaced by Mehlich-3 extractant after considerable longterm efforts and research and the approval by the UF/IFAS Plant Nutrient Oversight Committee (PNOC) in early 2020. Subsequent to the implementation of the Mehlich-3 procedure for this county, the test interpretation has been revised based on the research data as shown below.

Table 4. Soil test interpretation for Mehlich-3 extraction method for agronomic and horticultural crops and landscapes in Miami-Dade County.

\begin{tabular}{|c|c|c|c|}
\hline \multirow{2}{*}{ Nutrient } & Low & Medium & High \\
\cline { 2 - 4 } & & $\begin{array}{c}\text { (mg kg } \\
\text { - })\end{array}$ & \\
\hline $\mathrm{P}$ & $\leq 76$ & $77-104$ & $>104$ \\
\hline $\mathrm{K}$ & $\leq 85$ & $86-150$ & $>150$ \\
\hline
\end{tabular}

\section{Summary}

For sustainable management of all nutrients, particularly P, several physical and chemical properties of soils, landscape features, and sources of $\mathrm{P}$ have to be considered to maximize profits and minimize environmental losses. Soil testing programs primarily focus on the targeted soil $\mathrm{pH}$ range for enhanced solubility and efficient uptake. Higher $\mathrm{pH}$ ranges and application of Ca-based amendments can directly affect the solubility of applied $\mathrm{P}$ and can minimize plant uptake efficiency. Alkaline $\mathrm{pH}$ ranges can also affect the solubility of other plant-essential nutrients negatively and can result in limited success of soil test procedures and recommendations. Such management differences in the fields can result in inconsistent responses to added nutrient applications and render soil test interpretations ineffective.

Consideration of site-specific characters will help in choosing the right source, place, time, and rate of $\mathrm{P}$ application. Educational efforts on appropriate management strategies should be developed and provided to clientele. Long-term research and calibration work is needed to develop sitespecific interpretations and validations for different regions, crops, and management approaches in Florida.

\section{References}

Brown, J. R. 2012. Recommended Chemical Soil Test Procedures for the North Central Region. Columbia, MO: Missouri Agricultural Experiment Station, University of Missouri-Columbia.

Chuan, L., P. He, M. F. Pampolino, A. M. Johnston, J. Jin, X. Xu, S. Zhao, S. Qiu, and W. Zhou. 2013. "Establishing a Scientific Basis for Fertilizer Recommendations for Wheat in China: Yield Response and Agronomic Efficiency." Field Crops Research 140:1-8. https://doi.org/10.1016/j. fcr.2012.09.020

Heckman, J. R., W. Jokela, T. Morris, D. B. Beegle, J. T. Sims, F. J. Coale, S. Herbert, T. Griffin, B. Hoskins, J. Jemison, W. M. Sullivan, et al. 2006. "Soil Test Calibration for Predicting Corn Response to Phosphorus in the Northeast USA." Agronomy Journal 98 (2): 280-288. https://doi.org/10.2134/ agronj2005-0122

Hochmuth, G. J., R. Mylavarapu, and E. A. Hanlon. 2017a. Soil Testing for Plant-Available Nutrients-What Is It and Why Do We Use It? SL408. Gainesville: University of Florida Institute of Food and Agricultural Sciences. https://edis.ifas. ufl.edu/ss621

Hochmuth, G. J., R. Mylavarapu, and E. A. Hanlon. 2017b. Developing a Soil Test Extractant: The Correlation and Calibration Processes. SL409. Gainesville: University of Florida Institute of Food and Agricultural Sciences. https:// edis.ifas.ufl.edu/ss622

Hochmuth, G. J., R. Mylavarapu, and E. A. Hanlon. 2017c. Fertilizer Recommendation Philosophies. SL410. Gainesville: University of Florida Institute of Food and Agricultural Sciences. https://edis.ifas.ufl.edu/ss623 
Holford, I. C. R. 1980. “Greenhouse Evaluation of Four Phosphorus Soil Tests in Relation to Phosphate Buffering and Labile Phosphate in Soils." Soil Science Society of America Journal 44 (3): 555-559. https://doi.org/10.2136/ sssaj1980.03615995004400030024x

Kitchen, N. R., J. F. Shanahan, C. J. Ransom, C. J. Bandura, G. M. Bean, J. J. Camberato, P. R. Carter, J. D. Clark, R. B. Ferguson, F. G. Fernández, D. W. Franzen, et al. 2017. “A Public-Industry Partnership for Enhancing Corn Nitrogen Research and Datasets: Project Description, Methodology, and Outcomes." Agronomy Journal 109 (5): 2371-2389. https://doi.org/10.2134/agronj2017.04.0207

Liuzza, L. M., E. W. Bush, B. S. Tubana, and L. A. Gaston. 2020. "Determining Nutrient Recommendations for Agricultural Crops Based on Soil and Plant Tissue Analyzes between Different Analytical Laboratories." Communications in Soil Science and Plant Analysis 51 (3): 392-402. https://doi.org/10.1080/00103624.2019.1709488

Miller, R. O., R. Gavlak, and D. Horneck. 2013. "Soil, Plant and Water Reference Methods for the Western Region." 4th Edition. Accessed October 16, 2020. https://www. naptprogram.org/files/napt/publications/method-papers/ western-states-methods-manual-2013.pdf

Mylavarapu, R., W. Harris, and G. Hochmuth. 2019. Agricultural Soils of Florida. SL441. Gainesville: University of Florida Institute of Food and Agricultural Sciences. https://edis.ifas.ufl.edu/ss655

Mylavarapu, R. S., G. Hochmuth, and G. Liu. 2017. UF/ IFAS Standardized Nutrient Recommendations for Vegetable Crop Production in Florida. CIR1152. Gainesville: University of Florida Institute of Food and Agricultural Sciences. https://edis.ifas.ufl.edu/cv002

Mylavarapu, R. S., G. Hochmuth, C. Mackowiak, A. Wright, and M. Silveira. 2019. Lowering Soil pH to Optimize Nutrient Management and Crop Production. SL437. Gainesville: University of Florida Institute of Food and Agricultural Sciences. https://edis.ifas.ufl.edu/ss651

Mylavarapu, R., G. Hochmuth, V. Nair, A. Wright, J. McCray, and Y. C. Li. 2018. "Calibration of Soil Test Interpretations and Nutrient Recommendations for Major Commodities Grown across Florida as Best Management Practice for Sustainable Agriculture." Final Project Report, Grant Contract \# 024018, Florida Department of Agriculture and Consumer Services and University of Florida.
Mylavarapu, R., C. C. Mitchell, and H. J. Savoy. 2014. "Soils of the Southeastern US." In Soil Test Methods from the Southeastern United States, edited by F. J. Sikora and K. P. Moore, 2-10. Southern Cooperative Series Bulletin 419. Athens, GA: University of Georgia. http://aesl.ces.uga.edu/ sera6/PUB/MethodsManualFinalSERA6.pdf

Mylavarapu, R., K. Morgan, G. Hochmuth, M. Mulvaney, J. Dubeux, C. Mackowiak, and M. Ozores-Hampton. 2018. "Optimization of Predictive Soil Testing Methods for Implementation of Agricultural Best Management Practices." Final Report, NonPoint Source Management Program 319(h), G0411, University of Florida.

Mylavarapu, R., T. A. Obreza, K. Morgan, G. Hochmuth, V. Nair, and A. Wright. 2017. Extraction of Soil Nutrients Using Mehlich-3 Reagent for Acid-Mineral Soils of Florida. SL407. Gainesville: University of Florida Institute of Food and Agricultural Sciences. https://edis.ifas.ufl.edu/ss620

Mylavarapu, R. S., J. F. Sanchez, J. H. Nguyen, and J. M. Bartos. 2002. "Evaluation of Mehlich-1 and Mehlich-3 Extraction Procedures for Plant Nutrients in Acid Mineral Soils of Florida." Communications in Soil Science and Plant Analysis 33 (5-6): 807-820. https://doi.org/10.1081/ css- 120003067

Peaslee, D. E. 1978. "Relationships between Relative Crop Yields, Soil Test Phosphorus Levels, and Fertilizer Requirements for Phosphorus." Communications in Soil Science and Plant Analysis 9 (5): 429-442. https://doi. org/10.1080/00103627809366820

Sharpley, A., P. Kleinman, C. Baffaut, D. Beegle, C. Bolster, A. Collick, Z. Easton, et al. 2017. "Evaluation of Phosphorus Site Assessment Tools: Lessons from the USA." Journal of Environmental Quality 46 (6): 1250-1256. https://doi. org/10.2134/jeq2016.11.0427

Zhang, H., D. H. Hardy, R. Mylavarapu, and J. J. Wang. 2014. "Mehlich-3." In Soil Test Methods from the Southeastern United States, edited by F. J. Sikora and K. Moore, 101-110. Southern Cooperative Series Bulletin 419. Athens, GA: University of Georgia. http://aesl.ces.uga.edu/sera6/ PUB/MethodsManualFinalSERA6.pdf

Zhang, H., J. Antonangelo, J. H. Grove, D. L. Osmond, N. A. Slaton, S. Alford, R. J. Florence, G. Huluka, D. H. Hardy, J. T. Lessl, R. O. Maguire, R. S. Mylavarapu, et al. 2021 (in review). "Soil-Test-Based Phosphorus and Potassium Rate Recommendations across the Southeastern USA." SSSAJ. 
Table 3. Recommended phosphorus fertilizer for selected crops grown on organic soils in the Everglades Agricultural Area based on water-extractable phosphorus (Pw).

\begin{tabular}{|c|c|c|c|c|c|c|c|c|c|c|c|}
\hline $\begin{array}{c}\text { Pw } \\
\text { Index }\end{array}$ & Broccoli & Cabbage & Celery & $\begin{array}{l}\text { Field } \\
\text { corn }\end{array}$ & $\begin{array}{c}\text { Sweet } \\
\text { corn }\end{array}$ & $\begin{array}{c}\text { Crisphead } \\
\text { lettuce }\end{array}$ & Endive & Parsley & Radish & Romaine & $\begin{array}{c}\text { Snap } \\
\text { beans }\end{array}$ \\
\hline Ib/acre & \multicolumn{11}{|c|}{ Recommended $\mathrm{lb} \mathrm{P}_{2} \mathrm{O}_{5} /$ acre } \\
\hline 0 & 140 & 140 & 260 & 240 & 160 & 200 & 200 & 340 & 100 & 200 & 100 \\
\hline 1 & 140 & 140 & 260 & 240 & 160 & 200 & 200 & 340 & 100 & 200 & 100 \\
\hline 2 & 140 & 140 & 260 & 240 & 160 & 200 & 200 & 340 & 100 & 200 & 100 \\
\hline 3 & 140 & 140 & 260 & 240 & 160 & 200 & 200 & 340 & 100 & 200 & 100 \\
\hline 4 & 120 & 120 & 240 & 220 & 147 & 192 & 192 & 320 & 80 & 192 & 120 \\
\hline 5 & 100 & 100 & 220 & 200 & 133 & 183 & 183 & 300 & 60 & 183 & 100 \\
\hline 6 & 80 & 80 & 200 & 180 & 120 & 175 & 175 & 280 & 40 & 175 & 80 \\
\hline 7 & 60 & 60 & 180 & 160 & 107 & 167 & 167 & 260 & 20 & 167 & 60 \\
\hline 8 & 40 & 40 & 160 & 140 & 93 & 158 & 158 & 240 & 0 & 158 & 40 \\
\hline 9 & 20 & 20 & 140 & 120 & 80 & 150 & 150 & 220 & 0 & 150 & 20 \\
\hline 10 & 0 & 0 & 120 & 100 & 67 & 142 & 142 & 200 & 0 & 142 & 0 \\
\hline 11 & 0 & 0 & 100 & 80 & 53 & 133 & 133 & 180 & 0 & 133 & 0 \\
\hline 12 & 0 & 0 & 80 & 60 & 40 & 125 & 125 & 160 & 0 & 125 & 0 \\
\hline 13 & 0 & 0 & 60 & 40 & 27 & 117 & 117 & 140 & 0 & 117 & 0 \\
\hline 14 & 0 & 0 & 40 & 20 & 13 & 108 & 108 & 120 & 0 & 108 & 0 \\
\hline 15 & 0 & 0 & 20 & 0 & 0 & 100 & 100 & 100 & 0 & 100 & 0 \\
\hline 16 & 0 & 0 & 0 & 0 & 0 & 92 & 92 & 80 & 0 & 92 & 0 \\
\hline 17 & 0 & 0 & 0 & 0 & 0 & 83 & 83 & 60 & 0 & 83 & 0 \\
\hline 18 & 0 & 0 & 0 & 0 & 0 & 75 & 75 & 40 & 0 & 75 & 0 \\
\hline 19 & 0 & 0 & 0 & 0 & 0 & 67 & 67 & 20 & 0 & 67 & 0 \\
\hline 20 & 0 & 0 & 0 & 0 & 0 & 58 & 58 & 0 & 0 & 58 & 0 \\
\hline 21 & 0 & 0 & 0 & 0 & 0 & 50 & 50 & 0 & 0 & 50 & 0 \\
\hline 22 & 0 & 0 & 0 & 0 & 0 & 42 & 42 & 0 & 0 & 42 & 0 \\
\hline 23 & 0 & 0 & 0 & 0 & 0 & 33 & 33 & 0 & 0 & 33 & 0 \\
\hline 24 & 0 & 0 & 0 & 0 & 0 & 25 & 25 & 0 & 0 & 25 & 0 \\
\hline 25 & 0 & 0 & 0 & 0 & 0 & 17 & 17 & 0 & 0 & 17 & 0 \\
\hline 26 & 0 & 0 & 0 & 0 & 0 & 8 & 8 & 0 & 0 & 8 & 0 \\
\hline 27 & 0 & 0 & 0 & 0 & 0 & 0 & 0 & 0 & 0 & 0 & 0 \\
\hline 28 & 0 & 0 & 0 & 0 & 0 & 0 & 0 & 0 & 0 & 0 & 0 \\
\hline 29 & 0 & 0 & 0 & 0 & 0 & 0 & 0 & 0 & 0 & 0 & 0 \\
\hline 30 & 0 & 0 & 0 & 0 & 0 & 0 & 0 & 0 & 0 & 0 & 0 \\
\hline
\end{tabular}

